http:/ / dx.doi.org/10.30747/bfgez.67.2017.03

Wirginia Węglińska

\title{
W SOLIDARNOŚCI I OPORZE \\ DZIAŁALNOŚĆ KONSPIRACYJNA POLEK W KL STUTTHOF
}

\section{IN SOLIDARITY AND RESISTANCE : CLANDESTINE ACTIVITIES OF POLISH WOMEN IN THE STUTTHOF CAMP}

\author{
Powoli do równowagi dochodzity silniejsze duchowo jednostki, \\ usitowaty one wyrwać wspóttowarzyszki z beznadziejnej depresji* \\ Spiritually stronger individuals were slowly coming to balance, \\ they were trying to tear out their comrades from hopeless depression*
}

\section{Streszczenie:}

W latach 1940-1945 na terenie obozu Stutthof stopniowo rozwijały się różnego rodzaju formy kobiecej konspiracji. Aktywność więźniarek nie miała jednak zinstytucjonalizowanego charakteru, skupiając się przede wszystkim wokół działań o charakterze samopomocowym i kulturalnym. Uczestniczyły w niej kobiety, które przeważnie znajdowały się wyżej w hierarchii tej społeczności - posiadały zatrudnienie w obozowych warsztatach, obejmowały stanowiska funkcyjne, a także otrzymywały wsparcie poprzez kontakty z tzw. światem zewnętrznym. Ich działalność była również niezwykle istotnym wsparciem dla mężczyzn realizujących zadania obozowego ruchu oporu.

Słowa kluczowe: obozy koncentracyjne, ruch oporu, kobieca konspiracja, samopomoc, szpital obozowy, życie kulturalne, życie religijne, tajne nauczanie, XX wiek, II wojna światowa
Summary:

In the years 1940-1945, various forms of female clandestine activity gradually developed in the Stutthof camp. However, the activity of female prisoners was not institutionalized, focusing primarily on self-help and cultural activities. It involved women who were usually higher in the hierarchy of this community - those who were employed in the camp workshops, held some positions in the camp, or received support through contacts with the so-called outside world. Their activity constituted also an extremely important support for men carrying out the tasks of the camp resistance movement.
Key words: concentration camps, resistance movement, female clandestine activities, selfhelp, camp hospital, cultural life, religious life, secret education, the $20^{\text {th }}$ century, World War II

* Archiwum Muzeum Stutthof (dalej cyt.: AMS), H. Jarocka, Relacje i wspomnienia, t. VIII, s. 77. 
Viktor Frankl, austriacki psychiatra i psychoterapeuta, więzień obozów koncentracyjnych, w oparciu o analizę własnych doświadczeń wyodrębnił kilka kolejnych faz adaptacji do lagrowej egzystencji ${ }^{1}$. Pierwszą z nich charakteryzowały strach i szok, dotykające nowo przybyłych. Jej konsekwencją stawały się stany depresyjne, a niekiedy próby samobójcze. Z czasem, w wyniku nieustannego doświadczania obozowej brutalności, więźniowie obojętnieli. Tworząc niezbędną do przeżycia barierę, psychicznie uodporniali się na wszechobecną przemoc, a ich głównym celem stawało się przetrwanie, co w wielu wypadkach prowadziło do prymitywizacji zachowań i życia wewnętrznego².

Na losy więźnia i szybkość dostosowania się do sytuacji opresyjnej wpływał szereg rozmaitych czynników - okoliczności aresztowania, okres przybycia, znajomość języka niemieckiego, wykonywana profesja, przydział do komanda pracy, a także blok mieszkalny, w którym go umieszczono. Każdy z nich decydował o kierunku procesu adaptacji do nowych warunków. Jak podkreślał Kazimierz Godorowski, każdy więzień w momencie osadzenia posiadał inny stosunek emocjonalny do sytuacji, w jakiej się znalazł. Schwytani w łapance czy aresztowani za drobne przewinienia, tj. szmugiel lub kradzież, uwięzienie w obozie przeżywali jako niewspółmierną do przewinienia karę, co prowadziło do szybkiego załamania, a w konsekwencji nawet tzw. zmuzułmanienia ${ }^{3}$. Inaczej przedstawiała się sytuacja osób pojmanych za przynależność do ruchu oporu, przebywających uprzednio w aresztach Gestapo. Obóz był dla nich synonimem odroczenia na pewien czas wyroku śmierci. W pewnym sensie zahartowani i uodpornieni psychicznie, jak zauważa K. Godrowski, łatwiej wytwarzali właściwe mechanizmy przystosowawcze ${ }^{4}$.

Te były jednak zależne od ewentualnej asymilacji z odpowiednią grupą, która warunkowała przetrwanie. Konsolidacja w strukturze obozowego „miasta-państwa” nie leżała jednak w interesie władz SS, które za główny cel przyjęły „tworzenie społeczności konfliktowych, zróżnicowanych kulturowo i językowo, takich społeczności, w których miały szanse ujawnić się różne rodzaje antagonizmów" ${ }^{\prime \prime}$. Doskonale odzwierciedlał to kształt aparatu terroru, w którym - jak zakładano - tzw. stanowiska funkcyjne miały być obsadzone przez więźniów kryminalnych

${ }^{1}$ Zob. szerzej: V. Frankl, Człowiek w poszukiwaniu sensu, Warszawa 2014, ss. 222.

${ }^{2}$ Ibid., s. 56.

${ }^{3}$ K. Godorowski, Psychologia i psychopatologia hitlerowskich obozów koncentracyjnych. Próba analizy postaw i zachowań w warunkach ekstremalnych obciążen, Warszawa 1985, s. 49. Muzułmanin, muzułman - w żargonie obozowym (tzw. Lagersprache) słowo to oznaczało więźnia skrajnie wyczerpanego psychicznie i fizycznie.

${ }^{4}$ Ibid., s. 50.

${ }^{5}$ Cyt. za: A. Pawełczyńska, Wartości a przemoc. Zarys socjologicznej problematyki Oświęcimia, Warszawa 1973, s. 50. 
Wirginia Węglińska, W solidarności i oporze. Dziatalność konspiracyjna Polek...

zdolnych do przemocy i brutalności ${ }^{6}$. Okrutne traktowanie czy denuncjację współwięźniów nagradzano licznymi przywilejami. Społeczność obozowa miała zostać zastraszona, zgnębiona fizycznie i psychicznie, co powinno zgodnie z założeniami skutkować niezdolnością do współdziałania i jakiejkolwiek samoobrony. Jak podkreślał Wolfgang Sofsky: "masa zorganizowana pod przymusem to skrajnie patogenny stan społeczny"7.

Trudno jednak całkowicie zgodzić się z przywoływanym badaczem, który uważa, że fraternizacja społeczności więźniarskiej była jedynie przejściową koalicją lub spontanicznym sojuszem wobec nacisku $\mathrm{z}$ zewnątrz ${ }^{8}$. Zaprzeczają temu różnego rodzaju działania podejmowane przez więźniów w ramach szeroko rozumianego ruchu oporu. Nie powinno budzić wątpliwości, że nie dotyczyły one wszystkich osadzonych, a zaledwie niewielkich grup osób, które dzięki lepszej pozycji w obozie miały możliwość wykorzystania luk w stałym systemie kontroli i terro$\mathrm{ru}^{9}$. Szeroko zjawisko to opisał Krzysztof Dunin-Wąsowicz. Dowodził, że ruch oporu w obozach koncentracyjnych był niejako konsekwencją aktywności konspiracyjnej na terenach okupowanej Europy, podkreślając, że za przeniesienie jej w obozowe realia odpowiadali często ludzie działający uprzednio $\mathrm{w}$ podziemiu ${ }^{10}$.

Niewątpliwie ten rodzaj działalności podejmowany w obozach koncentracyjnych jest obecnie utożsamiany przede wszystkim $\mathrm{z}$ tajną organizacją funkcjonującą na terenie KL Auschwitz-Birkenau. Jest to związane m.in. $\mathrm{z}$ widocznym $\mathrm{w}$ ostatnich latach rosnącym zainteresowaniem postacią rotmistrza Pileckiego ${ }^{11}$. Rozmaite formy oporu możemy zaobserwować niemal we wszystkich obozach koncentracyjnych. Uczestniczyli w nich zarówno mężczyźni, jak i kobiety. Historia tych ostatnich jednak rzadziej staje się tematem badań historyków. Ciekawy przyczynek do

\footnotetext{
${ }^{6}$ Więźniowie funkcyjni stanowili pomocniczy (w stosunku do esesmańskiego) aparat nadzoru. W jego skład wchodzili m.in. blokowi, sztubowi i kapo. Szerzej o nich zob. m.in. Auschwitz od A do Z. Ilustrowana Historia Obozu, oprac. P. Cywiński, J. Lachendro, P. Setkiewicz, Oświęcim 2013, passim.

${ }^{7}$ Cyt. za: W. Sofsky, Ustrój terroru: obóz koncentracyjny, Warszawa 2016, s. 204.

${ }^{8}$ Ibid., s. 208.

${ }^{9}$ A. Pawełczyńska, op. cit., s. 136.

${ }^{10}$ K. Dunin-Wąsowicz, Ruch oporu w hitlerowskich obozach koncentracyjnych 1933-1945, Warszawa 1979, s. 48.

${ }^{11}$ Zob. A. Cyra, Rotmistrz Pilecki. Ochotnik do Auschwitz, Warszawa 2014, ss. 446; Auschwitz 1940-1945: węzłowe zagadnienia z dziejów obozu, pod red. W. Długoborskiego, F. Pipera, Oświęcim 1995, ss. 206; B. Jarosz, Organizacje obozowego i przyobozowego ruchu oporu i ich działalność, [w:] Auschwitz. Nazistowski obóz śmierci, pod red. F. Pipera, T. Świebockiej, Oświęcim 1993, s. 207-224.
} 
rozszerzenia dyskusji o roli i udziale więźniarek w obozowej konspiracji mogą stanowić wspomnienia Polek osadzonych w KL Stutthof.

Do tej pory relacje kobiet, dotyczacce ich udziału w oporze, rzadko stawały się przedmiotem osobnych rozważań badaczy, stanowiąc najczęściej tylko jeden $z$ elementów szerszej historii tego obozu ${ }^{12}$. Odwoływali się do nich w swoich opracowaniach m.in. Danuta Drywa, Krzysztof Dunin-Wąsowicz, Janina Grabowska-Chałka, Elżbieta Grot, Marcin Owsiński, Marek Orski oraz Krzysztof Steyer ${ }^{13}$. W 2016 r., nakładem Muzeum Stutthof w Sztutowie, ukazała się publikacja pt. Stutthof w kobiecych narracjach, składająca się ze wspomnień sześciu więźniarek - Anny Paszkowskiej, Heleny Jarockiej, Walerii Felchnerowskiej, Marii Pitery-Zalewskiej, Soni Anwajer i Maschy Rolnikaite - której fragmenty przybliżają działania konspiracyjne podejmowane przez kobiety w żeńskich częściach obozu ${ }^{14}$. Warto podkreślić, że to pierwsze opracowanie wspomnieniowe, w którym znalazły się relacje poświęcone wyłącznie kobiecym obszarom KL Stutthof ${ }^{15}$.

Podstawę źródłową niniejszego artykułu stanowią relacje i wspomnienia polskich więźniarek politycznych, będące bezsprzecznie największym zasobem informacji na temat omawianego zagadnienia. W oparciu o ich analizę autorka postara się nakreślić spektrum działań podejmowanych przez konspiratorki, ich formy, stopień trudności

${ }^{12}$ Wyjątkiem jest tu artykuł Danuty Drywy, zamieszczony w kwartalniku Uniwersytetu Jagiellońskiego. Zob. D. Drywa, „Nasz maty sabotaż” rola polskich więźniarek w życiu obozowym (legalnym i nielegalnym) KL Stutthof, Konteksty Kultury 2017, t. 14, z. 4, s. 465483.

${ }^{13}$ Zob. D. Drywa, Zagłada Żydów w obozie koncentracyjnym Stutthof, Gdańsk 2001, ss. 404; K. Dunin-Wąsowicz, op. cit.; J. Grabowska, Martyrologia kobiet i dzieci, [w:] Stutthof. Hitlerowski obóz koncentracyjny, praca zbiorowa, Warszawa 1988, s. 129-150; eadem, Przewodnik. Informator historyczny Muzeum Stutthof, Gdańsk-Sztutowo 2004, ss. 158; E. Grot, Eksterminacja pośrednia, [w:] Stutthof. Hitlerowski obóz koncentracyjny..., s. 179-215; M. Owsiński, Polscy więźniowie polityczni w obozie Stutthof 1939-1945, Toruń 2001, ss. 248; M. Orski, Niewolnicza praca więżniów obozu koncentracyjnego Stutthof w latach 1939-1945, Gdańsk 1999, ss. 400; K. Steyer, Samoobrona, sabotaż i inne formy oporu więźniów, [w:] Stutthof hitlerowski obóz..., s. 276-289; idem, Samoobrona, sabotaż i inne formy oporu więźniów w KL Stutthof, Zeszyty Muzeum Stutthof 1985, nr 6, s. 73-96.

${ }^{14}$ Autorka niniejszego artykułu przeanalizowała cytowaną publikację pod kątem obrazu sprawcy w narracjach kobiet, zob. W. Węglińska, Stutthof $i$ sprawcy zbrodni w narracjach więźniarek, [w:] Świadkowie: między ofiara a sprawca zbrodni, pod red. A. Bartuś, Oświęcim 2017, s. 45-71.

${ }^{15}$ W 1965 r. ukazała się książka więźniarki Anny Jędrychowskiej, która odwołuje się do sytuacji kobiet w Stutthofie. Drugą tego typu pozycją były wspomnienia Marii Suszyńskiej-Bartman poświęcone kobietom ewakuowanym z powstańczej Warszawy. Obie tylko w niewielkim stopniu przybliżają warunki w żeńskiej części obozu. Zob. A. Jędrychowska, Zygzakiem i po prostu, Warszawa 1975, ss. 372; M. Suszyńska-Bartman, Nieświęte męczennice, Warszawa 1971, ss. 253. 
i zakres oddziaływania. Wymienione materiały, gromadzone od lat 60 . XX w., znajdują się przede wszystkim w zbiorach Muzeum Stutthof w Sztutowie, a także w Fundacji Generał Elżbiety Zawackiej w Toruniu. Natomiast niektóre $\mathrm{z}$ nich nadal są w posiadaniu rodzin więźniarek KL Stutthof. Składają się na nie zarówno listy, fragmenty pamiętników, życiorysy, relacje, jak i wywiady udzielane pracownikom naukowym (w większości przez członkinie pomorskiego ruchu oporu).

Należy jednak zaznaczyć, że krytyka wymienionych źródeł nastręcza badaczom wielu trudności. Większość z nich powstawała kilkanaście, a nawet kilkadziesiąt lat po wojnie, co często skutkowało zniekształceniem obrazu minionych zdarzeń. Respondenci niejednokrotnie, z różnych przyczyn, nadawali większe znaczenie jednym wydarzeniom, a inne, niewygodne lub wstydliwe, woleli przemilczeć. Jak słusznie zauważa Marta Grudzińska, w tamtym czasie wielokrotnie wspomnienia obozowe były zgodne z ówczesną linią polityczną państwa komunistycznego ${ }^{16}$. Zamknięcie $\mathrm{w}$ martyrologiczno-heroicznych schematach doprowadzało niejednokrotnie do silnego kontrastowania rzeczywistości obozowej, a opisywanie jej niemal wyłącznie przez pryzmat walki lub cierpienia $\mathrm{w}$ znacznym stopniu utrudnia prześledzenie procesu kształtowania się obozowej konspiracji. Warto wspomnieć, że składane przez niektóre więźniarki relacje - jak się wydaje - miały m.in. na celu przedstawienie społeczności kobiecej w KL Stutthof w możliwie jak najlepszym świetle. Zapewne łatwiej było im także powracać do mniej traumatycznych przeżyć.

Badacze podejmujący $\mathrm{w}$ swoich pracach tematykę ruchu oporu w KL Stutthof najczęściej wyznaczają jego zakres, definicję i formę zgodnie z klasyfikacją opracowaną przez K. Dunin-Wąsowicza jeszcze w latach 70. Zakłada ona podział na trzy grupy form walki. Pierwszą z nich jest tzw. walka o biologiczne przetrwanie, w ramach której organizowano szeroko rozumianą wzajemną pomoc, kontakty ze światem zewnętrznym czy też zdobywanie miejsca w pomocniczym aparacie nadzoru. Kolejna grupa odnosi się do walki o zachowanie godności ludzkiej, przez co należy rozumieć wszelkiego rodzaju przejawy życia kulturalnego, w jakich uczestniczyli więźniowie. Ostatni, trzeci element stworzonej przez K. Dunin-Wąsowicza klasyfikacji obozowego ruchu oporu, to walka o bezpośrednie zaszkodzenie systemowi hitlerowskiemu, a więc dzia-

${ }^{16}$ M. Grudzińska, O czym mówia byli więźniowie Majdanka? Doświadczenia osobiste a pamięć publiczna, [w:] Świadkowie: między ofiarą..., s. 23. Szerzej o instrumentalnym traktowaniu tematyki byłych obozów koncentracyjnych pisze m.in. Joanna Wawrzyniak. Zob. J. Wawrzyniak, Zbowid i pamięć drugiej wojny światowej 1949-1969, Warszawa 2009, passim. 
łalność sabotażowa, ucieczki i funkcjonowanie zorganizowanych grup konspiracyjnych ${ }^{17}$.

Chociaż przywoływana przez niego charakterystyka ruchu oporu, którego sam był członkiem, stanowi nadal podstawę do rozważań na temat konspiracji w KL Stutthof, nie wszystkie jej elementy znajdują odbicie w tajnej działalności podejmowanej przez osadzone w nim kobiety. Ich aktywność w obozie odwzorowywały raczej zadania, do których zostały przeszkolone i jakie wykonywały przed aresztowaniem, podczas pełnienia służby kurierek i łączniczek w Polskim Państwie Podziemnym ${ }^{18}$. Należy zaznaczyć, że kobiety raczej w niewielkim stopniu brały udział w czynnej, bezpośredniej walce, mającej na celu zaszkodzenie władzom obozowym. W miarę swoich możliwości prowadziły one różnego rodzaju akcje samopomocowe i rozwijały życie kulturalne, nie organizując ucieczek ani konspiracji zbrojnej ${ }^{19}$. Niewątpliwie zaangażowanie kobiet w obozowy ruch oporu stanowiło cenne wsparcie dla mężczyzn realizujących jego zadania, nie miało ono jednak zinstytucjonalizowanego charakteru. Warto również zauważyć, że w wielu wypadkach wspomnianą działalność realizowano spontanicznie, za sprawą jednorazowych inicjatyw poszczególnych osób, nie uwzględniając jakichkolwiek zasad konspiracji. Działalność Polek w obozie Stutthof należałoby zatem rozpatrywać nie w kategoriach zorganizowanego ruchu oporu, a jako realizację wezwania o „solidarności społeczeństwa, wspieranie bliźniego Polaka wszędzie, gdzie grozi mu zguba lub nędza"20.

Historia części żeńskiej w Stutthofie sięga czerwca 1940 r., a więc okresu, kiedy nie posiadał on statusu państwowego obozu koncentra-

${ }^{17}$ Zob. K. Dunin-Wąsowicz, op. cit., s. 52-53.

${ }^{18}$ Niezwykle cenne informacje o działalności pomorskich konspiratorek znajdują się w publikacji: B. Chrzanowski, A. Gąsiorowski, K. Steyer, Polska podziemna na pomorzu w latach 1939-1945, Gdańsk 2005, ss. 660. Więcej o działaniach kobiet w strukturach Polskiego Państwa Podziemnego zob. także: B. Drapikowska, Kobiety w Polskiej Armii - ujęcie historyczne, Czasopismo Naukowe Instytutu Studiów Kobiecych 2016, nr 1, s. 55-62; A. Herbich, Morowe Panny. Kobiety z Armii Krajowej, [w:] Wielka ksiega Armii Krajowej, praca zbiorowa, Kraków 2015, s. 454-507 (wydanie elektroniczne); A. Piertowicz, Babska siatka, Biuletyn IPN 2011, nr 5, 6, s. 39-53; A. Rybińska, Rola, działalność i znaczenie kobiet w Armii Krajowej. Wybór biografii regionu łódzkiego, Toruń 2016, ss. 157; Z. Zieliński, Kobiety - żotnierze Armii Krajowej w Okręgu Radomsko-Kieleckim "Jodła”, Niepodległość i Pamięć 2003, nr 10/1 (19), s. 179-187. Artykuły traktujące o historii kobiet konspiratorek od lat publikowane są również na łamach biuletynu wydawanego przez Fundację Generał Elżbiety Zawackiej, a także w Stowniku biograficznym konspiracji pomorskiej.

${ }^{19} \mathrm{~K}$. Steyer w jednym ze swoich artykułów, powołując się na wspomnienia B. Sruogi, odnotowuje fakt ucieczki jednej z Rosjanek. Nie ma jednak danych o ewentualnych innych ucieczkach (lub ich próbach) kobiet. Zob. K. Steyer, Z problematyki ucieczek z KL Stutthof, Stutthof. Zeszyty Muzeum 1977, nr 2, s. 187.

${ }^{20} 10$ przykazań walki cywilnej, Biuletyn Informacyjny 7 V 1942, nr 18. 
cyjnego. Początkowo, tj. do 1942 r., przebywały w nim głównie polskie więźniarki polityczne i wychowawcze. Grupa tzw. stałych więźniarek, osadzonych bezterminowo, nie przekraczała we wspomnianym okresie 50 osób ${ }^{21}$. W latach 1942-1943 liczba uwięzionych kobiet stale wzrastała, stopniowo rozszerzał się także skład narodowościowy. Obok Polek zaczęto w tym okresie osadzać również Rosjanki, Niemki, Dunki, Norweżki, Finki, Litwinki, Estonki i Łotyszki. Niewątpliwie przełomowy okres w historii części żeńskiej stanowiła druga połowa 1944 r., kiedy to, m.in. za sprawą licznych transportów więźniarek narodowości żydowskiej, liczba kobiet wzrosła do 36376 (łącznie z podobozami) ${ }^{22}$. Przez pierwsze lata istnienia Stutthofu kobiety więziono w blokach na terenie tzw. starego obozu. Dopiero w 1944 r., w związku z gwałtownym wzrostem liczby uwięzionych w części żeńskiej, baraki kobiece (osobne dla aryjek i żydówek) powstały także w nowym obozie.

Początkowo, tj. w latach 1940-1942 r., stworzenie jakichkolwiek zrębów konspiracji w bloku żeńskim było niezwykle trudne. Okres ten, podobnie jak $\mathrm{w}$ innych obozach koncentracyjnych, charakteryzował szczególny terror i ciężkie warunki bytowe. Dopiero od 1942 r. funkcjonowanie sytemu lagrowego zaczęło skupiać się przede wszystkim wokół czynników ekonomicznych. W tym okresie więźniowie obozów koncentracyjnych stawali się bowiem coraz istotniejszym elementem $\mathrm{w}$ planach gospodarki wojennej nazistowskich Niemiec ${ }^{23}$. Z jednej strony następowało więc relatywne polepszenie warunków życia w obozach - zezwolono na przysyłanie paczek ${ }^{24}$, wprowadzono formalny zakaz bicia, a także wolne od pracy niedzielne popołudnia ${ }^{25}$. $\mathrm{Z}$ drugiej strony $\mathrm{w}$ omawianym okresie dochodziło także do największych morderstw na wybranych grupach więźniów, ogromnego przeludnienia, rozprzestrzeniania się epidemii i wysokiej śmiertelności, z uwagi na całość panujących w obozie warunków bytowych. Pomimo utrzymania systemu represji zapoczątkowane w 1942 r. zmiany stworzyły sytuację, w której pewne grupy osadzonych uzyskały możliwość organizowania struktur ruchu oporu. Warto przy tym zauważyć, że na powstanie konspiracji w bloku kobiecym wpłynął

${ }^{21}$ J. Grabowska, Martyrologia kobiet i dzieci..., s. 130-131.

${ }^{22}$ Ibid., s. 132.

${ }^{23} \mathrm{~W}$ interesujący sposób kwestie niewolniczej siły roboczej więźniów omawia N. Wachsmann w rozdziale Gospodarka i eksterminacja zob. N. Wachsmann, KL. Historia nazistowskich obozów koncentracyjnych, Warszawa 2016, passim.

${ }^{24}$ Zakaz przesyłania paczek do obozów koncentracyjnych złagodzono po raz pierwszy we wrześniu 1941 r. Natomiast od października 1942 r. zniesiono go całkowicie. Liczba przesyłanych paczek ani jej zawartość nie podlegały już ograniczeniom. Zob. J. Mozdan, Historia Poczty obozu koncentracyjnego na Majdanku. O obozie, ludziach i listach, Manching 2010, s. 52.

${ }^{25}$ Szerzej na temat czasu pracy więźniów zob. M. Orski, op. cit., s. 133-136. 
zasadniczo jeszcze jeden czynnik. Mowa tu o uwięzieniu w Stutthofie, na przełomie lat 1942 i 1943, większych grup działaczek konspiracyjnych, które prowadzoną wcześniej na terenie okupowanego kraju działalność starały się kontynuować w obozie. Należały do nich m.in. Kazimiera Bartel, Helena Chrzanowska, Cecylia Ciesielska, Waleria Felchnerowska, Helena Jarocka, Elżbieta Marcinkowska, Maria Pitera-Zalewska, Halina Strzelecka, Helena Stawska, Jadwiga Stenzel czy Maria Witt ${ }^{26}$.

W tworzeniu kobiecej konspiracji w KL Stutthof przeważnie brały udział więźniarki, które znajdowały się wyżej w hierarchii tej społeczności - tzn. posiadały zatrudnienie w ważniejszych komandach, obejmowały stanowiska funkcyjne, otrzymywały paczki żywnościowe. Kobiety-konspiratorki tworzyły przeważnie kilku- maksymalnie kilkunastoosobowe grupy, których priorytetem było wzajemne utrzymywanie się przy życiu. Starano się to realizować przez szerokie spektrum działań - jak na przykład samopomoc, aktywność kulturalną, a także tajne nauczanie. Nie brakowało również doraźnych przedsięwzięć wspierających inne grupy uwięzionych. Nie miały one jednak ciągłego charakteru. Niezwykle trudno określić zasięg podejmowanych wówczas działań samopomocowych czy kulturalnych. Zazwyczaj, jak można wnioskować z zachowanych źródeł, ograniczały się one do obrębu bloku, sztuby czy komanda pracy. Należy również zaznaczyć, że omawiane relacje nie mogą być reprezentatywne dla całej kobiecej społeczności więźniarskiej. Jak podkreśla Bernhard Strebel, analizując pogląd Germaine Tillion, różnice warunków, w jakich przebywali poszczególni więźniowie, były większe niż „między poziomem życia królowej angielskiej a mieszkankami londyńskiej noclegowni" 27 .

Jak zostało już zaznaczone we wstępie niniejszego artykułu, okres przyjęcia i pierwszych tygodni spędzonych w obozie miał w wielu przypadkach wyraźny wpływ na dalsze losy więźniów. Kobiety podczas tzw. ceremonii powitalnej niejednokrotnie bito, poniżano i poddawano upokarzającym badaniom. Jeśli nowo przybyłe spotkały się z serdecznym przyjęciem ze strony tzw. starych numerów, ich sytuacja mogła ulec zasadniczej zmianie. Psychiczne wsparcie, jakie otrzymywały od innych, pozwalało na znacznie szybsze wykształcenie tzw. mechanizmów przetrwania. Część więźniarek politycznych, wiedząc, jak trudne są pierwsze momenty spędzone w Stutthofie, starała się nieść nowym pomoc, której tak bardzo potrzebowały. Potwierdza to m.in. relacja Ireny Wegner, która wspomina: „koleżanki, które przyjechały wcześniej ułatwiły

${ }^{26}$ Szerzej o tych transportach zob. J. Grabowska, Martyrologia kobiet i dzieci..., s. 129$-150$.

${ }^{27}$ Cyt. za: B. Strebel, KL Ravensbrück. Historia kompleksu obozów, Gdańsk 2018, s. 21. 
nam pierwszy kontakt $\mathrm{z}$ obozem, one dodawały nam otuchy" ${ }^{28}$. W tym samym tonie wypowiada się Maria Liberacka: „Dzięki szczególnie serdecznej i koleżeńskiej postawie takich pań jak: Jadwiga Rotecka, Halina Strzelecka, Ludwika Stencel i E. Marcinkowska (Szuca) i wielu innych bez większych kłopotów zaaklimatyzowałam się w obozie" ${ }^{29}$. Zdarzało się także, że w trakcie oczekiwania na przyjęcie do obozu starsze więźniarki oferowały pomoc $\mathrm{w}$ przechowaniu cennych przedmiotów, które odbierano podczas rewizji. Był to niejednokrotnie jedyny sposób na zachowanie ważnej, osobistej pamiątki ${ }^{30}$.

Należy jednak przyznać, że serdeczne przyjęcie do bloku nie było regułą. Mogły na to liczyć przeważnie kobiety pochodzące z podobnego środowiska. Do „obcych" podchodzono często z rezerwą i nieufnością. Realia obozowe określały swoisty system wartości i inne niż na wolności zasady zachowania. Musimy pamiętać, że dodatkowe osoby w bloku oznaczały zaburzenie wyznaczonego dotychczas porządku. Zabierały miejsce, a także wprowadzały niepewność w świecie, w którym obawiano się szpiclów. Zdarzały się także przypadki, że nowo przybyłe spotykały się z wrogością ze strony pozostałych. Jedna $\mathrm{z}$ takich sytuacji miała miejsce jesienią 1944 r., kiedy do KL Stutthof skierowano kobiety z Powstania Warszawskiego ${ }^{31}$.

Ważnym elementem opieki nad psychiką więźniarek było również urządzanie różnego rodzaju uroczystości, świąt patriotycznych i religijnych, a także wieczorków muzycznych czy teatralnych. Było to o tyle ważne, gdyż w pierwszych dwóch latach istnienia części żeńskiej w KL Stutthof zabraniano organizowania działalności kulturalnej, a jakiekolwiek próby jej podejmowania mogły się zakończyć ciężkimi represjami. Sterroryzowanym, wycieńczonym więźniarkom w każdej chwili groziło niebezpieczeństwo. Dobrze odzwierciedla to relacja Marii Pitery-Zalewskiej odnosząca się do Bożego Narodzenia 1941 r.: „zaczyna się w nas coś buntować, sprzeciwiać zakazom. I kilka z nas postanawia chociaż półgłosem zanucić kolędę. Ale czy nam się to uda? Czy ktoś nie zdradzi? Niech się dzieje co chce, niech nas nawet obiją tak, żebyśmy się ruszać już nie mogły [...] Uradziłyśmy wtedy, że kiedy już wszyscy pójdą spać, urządzimy pasterkę. [...] Wtem słychać pod oknami skrzyp śniegu, po chwili silne szarpnięcie i do drzwi izby $\mathrm{z}$ mroźnym powietrzem $\mathrm{w}$ tumanie pary wszedł Blockführer, zwany przez nas »Bombą« [...] Izbowa stanęła na baczność w nocnej bieliźnie, meldując stan izby. Na zapytanie,

${ }^{28}$ AMS, I. Wegner, Relacje i wspomnienia, t. XVI, s. 159.

${ }^{29}$ AMS, M. Liberacka, Relacje i wspomnienia, t. X, s. 51-52.

${ }^{30}$ AMS, M. Pitera-Zalewska, Relacje i wspomnienia, t. XV, s. 251.

${ }^{31}$ Zob. W. Węglińska, Historia 40 tączniczek $i$ sanitariuszek osadzonych 29 września 1944 r. w KL Stutthof, Zeszyty Muzeum Stutthof 2015, nr 3 (13), s. 137-138. 
czy wszystko jest w porządku odpowiedziała: »Tak jest «, ale z miejsca dostała silny policzek, od którego aż się zatoczyła"32.

Jedne $\mathrm{z}$ pierwszych potajemnie zorganizowanych uroczystości patriotycznych urządzono w ramach Zaduszek 1942 r. Podczas nich odbył się „apel poległych”, na którym kobiety wspominały i z godnością żegnały zamordowanych przez Niemców bliskich ${ }^{33}$. Kilka tygodni później więźniarki po raz pierwszy urządziły skromną gwiazdkę $e^{34}$. Podobnie jak w przypadku innych form kobiecej konspiracji działalność artystyczna rozwinęła się $\mathrm{w}$ ciągu następnych dwóch lat istnienia obozu. Wigilię 1943 r. obchodzono już, jak na obozowe realia, bardzo uroczyście. Władze SS wydały wówczas dodatkową porcję żywności ${ }^{35}$. Na polepszenie sytuacji aprowizacyjnej wpłynęły także paczki nadesłane przez rodziny więźniarek. Według wspomnień J. Roteckiej kobiety przyjęły także komunię świętą ${ }^{36}$. Po kolacji przygotowano przekazywane między sztubami jasełka. Figurkę dzieciątka Jezus i zwierzątka ulepiono z gliny. Mężczyźni pracujący w stolarniach zbudowali niewielką szopkę i żłobek. Więźniarki odegrały resztę postaci. H. Chrzanowska została narratorem, J. Rotecka Świętym Józefem, a w Matkę Boską wcieliła się Czesława Kupis. Byli także pasterze i Herod. Parafrazowano kolędy tak, aby odzwierciedlały one aktualną w obozie sytuację. Jak wspominają więźniarki, przedstawienie wprowadziło pewne ożywienie w obozowej rzeczywistości. W zbiorach Muzeum Stutthof zachował się oryginalny, spisany przez Halinę Banasiak scenariusz tych występów ${ }^{37}$. Niektóre grupy kobiet podarowały koleżankom drobne prezenty. H. Jarocka wspominała, że w warsztacie wyrobów ze słomy i celofanu nielegalnie przygotowano niewielkie wisiorki i przedmioty użytku osobistego ${ }^{38}$.

Najlepiej zorganizowana była jednak Wigilia 1944 r. W Stutthofie panowało wówczas względne rozluźnienie rygoru obozowego. W nadzorowaniu więźniów esesmanów zastępowali często kalecy żołnierze Wehrmachtu, którzy nie przywiązywali większej wagi do dyscypliny ${ }^{39}$.

\footnotetext{
${ }^{32}$ AMS, W. Felchnerowska, Relacje i wspomnienia, t. III, s. 70-71.

${ }^{33}$ AMS, H. Jarocka, Relacje i wspomnienia, t. XVIII, s. 96-97.

${ }^{34}$ Ibid., s. 78.

${ }^{35}$ Relacja J. Roteckiej przekazana przez A. Szewczuk-Mielczarek. W zbiorach własnych autorki.

${ }^{36}$ P. Cieślawski, Nauczycielka hm. Jadwiga Rotecka-Szewczuk 1911-1959, Gdynia 1992, s. 60 .

${ }^{37}$ AMS, Obozowy ruch oporu, sygn. III-III-2.

${ }^{38}$ Warsztat produkcji ze słomy i celofanu (w oficjalnej nomenklaturze nosił on nazwę Strohschuhmacherstube) zorganizowano na polecenie władz obozu w styczniu 1943 r. Więźniarki wyplatały w nim obuwie ze słomy. Zob. szerzej M. Orski, Niewolnicza praca..., s. 149.

${ }^{39}$ K. Steyer, Samoobrona, sabotaż i inne formy oporu..., s. 285.
} 
Ponadto, jak wspomina jedna z więźniarek: „to wszystko było możliwe dlatego, że na Gwiazdkę wyjeżdżały niektóre wachmanki i nie byłyśmy tak bardzo pilnowane" ${ }^{\prime 0}$. Na podstawie zachowanych źródeł można odtworzyć m.in. przebieg Wigilii 1944 r., która odbyła się w szubie nr 3 bloku nr $1^{41}$. Składała się ona z dwóch części - religijnej i artystycznej. Pierwszą zorganizowano przy prowizorycznym ołtarzu. Dzięki „łączniczkom" udało się także przemycić ukrywane w pralni komunikanty. Schowano je w specjalnej szkatułce na ołtarzu, obok którego postawiono małą szopkę. W jej centralnym punkcie znajdował się żłóbek ${ }^{42}$. Po dwóch stronach umieszczono lalki ubrane $\mathrm{w}$ stroje ludowe, wykonane przez Stefanię Miotk ${ }^{43}$. Wieczór rozpoczął się czytaniem mszału, a następnie kazania napisanego przez ks. Sylwestra Niewiadomego ${ }^{44}$. Chórek, któremu Stefania Osowska miała akompaniować na skrzypcach, odśpiewał kolędy ${ }^{45}$. Po kolacji wigilijnej nastąpiła tzw. część rozrywkowa. Składały się na nią różnego rodzaju występy. Ponadto W. Felchnerowska, nazywana w obozie "ciocią Walą", wraz z kilkoma dziewczętami kolędowała z programem pastorałek ${ }^{46}$.

W blokach kobiecych organizowano również inne uroczystości religijne. Wspólne modlitwy, w największej tajemnicy "śpiewane" szeptem pieśni nie tylko podnosiły na duchu, ale przede wszystkim kształtowały pewnego rodzaju wspólnotę. $\mathrm{W}$ oparciu o zachowane relacje można przytoczyć wyjątki z życia religijnego na terenie tzw. starego obozu (w izbach nr 3 i 6). Modlitwy o tematyce lagrowej układała H. Strzelecka, a religijne pieśni śpiewała Barbara Mrotek ${ }^{47}$. W zbiorach Muzeum Stutthof zachowała także książeczka do nabożeństwa wykonania nielegalnie dla "cioci Wali” w KL Stutthof w grudniu 1944 r. ${ }^{48}$ Więźniarki same,

${ }^{40}$ Stutthof w kobiecych narracjach..., s. 94.

${ }^{41}$ Archiwum rodzinne L. Zięby, wspomnienia H. Jarockiej pt. Harcerki w Stutthofie, s. 10. Kopia relacji w zbiorach autorki.

${ }^{42}$ Ibid.

${ }^{43} \mathrm{~W}$ zbiorach muzeum Stutthof znajdują się dwie kukiełki z tego przedstawienia http://stutthof.org/node/392 [dostęp 20 XI 2018].

${ }^{44}$ Oryginał kazania znajduje się w zbiorach Muzeum Stutthof (zob. AMS, ruch oporu, III-II-26).

${ }^{45} \mathrm{~W}$ niektórych, uprzywilejowanych blokach więźniowie (nienależący do obozowej orkiestry) mogli także posiadać instrumenty muzyczne. Wspomina o tym m.in. Bronisław Nietyksza. Relacjonuje on, że w bloku 15, w którym przebywał, znajdowało się pianino. Zob. B. Nietyksza, Nadzieje, złudzenia, rzeczywistość. Wspomnienia z lat 1912-1945, Warszawa 1985, s. 355.

${ }^{46}$ Archiwum rodzinne L. Zięby, wspomnienia H. Jarockiej pt. Harcerki w Stutthofie, s. 10. Kopia relacji w zbiorach autorki.

${ }^{47}$ Teksty modlitw zachowały się m.in. w spisanym przez H. Jarocką modlitewniku. Obecnie znajduje się on w archiwum rodzinnym L. Zięby (kopia w zbiorach autorki).

${ }^{48}$ stutthof.org/node/392 [dostęp 20 XI 2018]. 
potajemnie, odprawiały także różnego rodzaju nabożeństwa i przygotowywały dewocjonalia, których najpopularniejszą formą były różańce z chleba i sznurka ${ }^{49}$.

Ważną rolę w życiu religijnym kobiet odegrało uwięzienie w KL Stutthof litewskiego księdza Alfonsasa Lipniūnasa. Należał on do grupy litewskich więźniów, tzw. Ehrenhäftlingów, którzy mieli większe możliwości poruszania się po obozie i szersze kontakty ze światem zewnętrznym $^{50}$. To właśnie ksiądz A. Lipniūnas 14 VIII 1943 r. udzielił kobietom zbiorowej absolucji. Jak wspomina jedna z uczestniczek tego wydarzenia: „kapłan Litwin na umówiony znak zza drutów z obozu męskiego udzielał absolutorium wtajemniczonym" ${ }^{\prime \prime 1}$. Pierwsza komunia święta dla kobiet w KL Stutthof odbyła się następnego dnia w warsztacie wyrobów ze słomy i celofanu. Jeszcze przed apelem, kiedy w obozie panowało największe zamieszanie, kobiety w 2-3-osobowych grupkach udawały się do warsztatu, gdzie otrzymywały sakrament ${ }^{52}$.

Kolejne takie zdarzenie, o czym była już mowa w relacji J. Roteckiej, miało miejsce w Boże Narodzenie 1943 r. Wówczas to ks. A. Lipniūnas, najpierw stojąc za ogrodzeniem w męskiej części obozu, udzielał absolucji, a następnie - $\mathrm{w}$ jednej $\mathrm{z}$ izb - komunii. Wtajemniczonych $\mathrm{w}$ całe przedsięwzięcie miało być wówczas około 45 osób ${ }^{53}$. Następną komunię świętą zorganizowano na Wielkanoc 1944 r. Warto wspomnieć, że więźniarki, które miały możliwość częstszych kontaktów z duchownymi, przez pewien czas przyjmowały ją $\mathrm{w}$ pierwsze piątki miesiąca ${ }^{54}$. Praktyki religijne miały dla niejednokrotnie chorych, walczących $\mathrm{z}$ depresją kobiet ogromne znaczenie. Świadczą o tym m.in. słowa jednej z więźniarek: „w tej silnej i głębokiej depresji - Komunia święta była tym pokarmem co zasilał ducha i krzepił wiarę $\mathrm{w}$ wolność. Tym liczniej garnęłyśmy się po tę moc ukrytą w Najświętszym Sakramencie. Stąd także większe święto jak: Zielone Święta 15 sierpnia, Wszystkich Świętych, gwiazdka 1944 były okazjami do komunikowania. W Komunii św. brały udział mieszkanki izb nr 1, 2, 3, 4, 5 i 6 w liczbie około 50-60 osób ${ }^{\prime 55}$. Według H. Strzeleckiej

${ }^{49}$ AMS, Relacja E. Marcinkowskiej-Szucy, nagranie wideo. Szerzej o wyrabianiu przez więźniów dewocjonaliów pisał także W. Wysocki. Zob. szerzej: W. Wysocki, Bóg na nieludzkiej ziemi, Warszawa 1982, s. 160-167.

${ }^{50}$ Kategorię więźniów honorowych (tzw. Ehrenhäftlinge) nadano 47 Litwinom osadzonym w KL Stutthof 26 III 1943 r.

${ }^{51}$ Relacja E. Marcinkowskiej-Szucy, [w:] J. Antanaviius, R. Gasparaitytè, E. Grot, Ksiądz Alfonsas Lipniūnas w relacjach i wspomnieniach więźniów obozu KL Stutthof, Gdynia 2002, s. 60 .

${ }^{52}$ Ibid.

${ }^{53}$ Ibid.

${ }^{54}$ Ibid., s. 61.

${ }^{55}$ Ibid. 
ostatni raz sakramentu komunii świętej na terenie obozu udzielono na początku 1945 r. Przyjęła go wówczas chora na tyfus kobieta ${ }^{56}$.

Poza celebrowaniem świąt i praktyk religijnych więźniarki organizowały także różnego rodzaju występy, wieczory literackie, "filmowe”, nielegalne kursy i dyskusje naukowe ${ }^{57}$. Realizowano je - jak relacjonuje wiele kobiet $-\mathrm{w}$ niewielkich grupach, tak aby nie skupiać na sobie uwagi więźniów funkcyjnych. W jednym $\mathrm{z}$ „monodramów” W. Felchnerowska odgrywała rolę dyrektora ogrodu zoologicznego. Miała na sznurku maskotki zwierząt, m.in. słonie, zebry, wilka i jelenia, wykonane na miarę obozowych możliwości. Dla każdego z nich ułożyła satyryczny wiersz, dowcipnie charakteryzujący bieżące sprawy obozowe. Zestawiała wówczas sytuację uwięzionych ludzi i zwierząt. Jak sama wspominała: porównywałam te zwierzątka $\mathrm{z}$ nami, z naszą sytuacją, na przykład zebrę zestawiałam z naszymi pasiakami, to, że kot łapie myszy, a my wszy i inne ${ }^{58}$. W. Felchnerowska swoją postawą, pomysłowością i anegdotami skłaniała do śmiechu nawet najsmutniejsze więźniarki ${ }^{59}$. Wyobraźnię kobiet pobudzały także Dorota Szklarska relacjonująca zapamiętane z wolności filmy i H. Strzelecka komentująca i streszczająca powieści. Ich barwna narracja, lapidarny styl i ogromny talent do budowania napięcia skupiały spore grono słuchaczek ${ }^{60}$. W następujący sposób takie spotkania zapamiętała jedna z ich uczestniczek: „,wieczorami, gdy leżałyśmy na pryczach i objadane [byłyśmy - W.W.] przez różne insekty, nie mogłyśmy spać, przenosiłyśmy się myślami w kinowy świat [...] te literackie i filmowe opowieści były dla nas ucieczką przed zmorą obozu. Były nawrotem do normalnego życia, chociaż na tę jedną godzinę" ${ }^{\prime \prime 1}$.

Ogromną wartość miały także wszelkiego rodzaju wiersze, prezenty w postaci laurek, kartek okolicznościowych czy drobnych przedmiotów wykonywanych w obozie ${ }^{62}$. Tego rodzaju działalność, czego dowodem

\footnotetext{
${ }^{56}$ Relacja H. Strzeleckiej, [w:] J. Antanaviius, R. Gasparaitytė, E. Grot, op. cit., s. 70.

${ }^{57} \mathrm{~W}$ ciekawy sposób tajną edukację w obozach koncentracyjnych przybliża także publikacja: Tajne Nauczanie w KL Ravensbrück. "A ja wtaśnie przed śmiercia chcę wiedzieć jak najwięcej", pod red. M. Janik, E. Kuszyk-Peciak, Sztutowo 2015, ss. 100.

${ }^{58}$ AMS, W. Felchnerowska, Relacje i wspomnienia, t. III, s. 68.

${ }^{59}$ AMS, H. Jarocka, Relacje i wspomnienia, t. XVIII, s. 89.

${ }^{60}$ Ibid., s. 78.

${ }^{61}$ Ibid.

${ }^{62}$ Szerzej o tego rodzaju działalności więźniów KL Stutthof zob. D. Drywa, Twórczość obozowa więźniów obozu koncentracyjnego Stutthof, Sztutowo, b.r., ss. 20. Informacje o twórczości artystycznej więźniów znajdują się także na stronie Muzeum Stutthof w Sztutowie w zakładce obiekt miesiąca http:// www.stutthof.org/obiektmiesiaca [dostęp 20 XI 2018].
} 
są licznie zachowane artefakty, ucieleśniała często tęsknotę, pragnienie wolności i powrotu do najbliższych ${ }^{63}$.

Ważną formą udzielania psychicznego wsparcia było także tajne nauczanie. Realizowano je w kilku formach - kursów, wykładów i dyskusji naukowych dla starszych kobiet, a także lekcji dla nastoletnich dziewcząt. Na przykład w 1943 r. więźniarki odrywały się od obozowej rzeczywistości, ucząc się przepisów kulinarnych. Jedna z uczestniczek takiego kursu wspominała: „łykając ślinę, marzyłyśmy, że kiedy wrócimy do domu, to naszym najbliższym przyrządzimy te wszystkie smakowite potrawy" ${ }^{\prime \prime}$. Kartki z notatkami przechowywano w siennikach ${ }^{65}$. Niestety, żadna z nich nie zachowała się do naszych czasów. Zorganizowano również potajemny kurs sanitarny, gdyż kobiety uważały, że muszą być przygotowane na wypadek wybuchu epidemii czy też buntu w Stutthofie. Odbywał on się przez kilka wieczorów. W jego ramach lekarka Anna Paszkowska prowadziła wykłady poświęcone objawom i leczeniu chorób obozowych (przede wszystkim tyfusu i biegunki). Natomiast H. Chrzanowska opowiadała o składzie apteczki, a J. Rotecka uczyła bandażowania ${ }^{66}$.

Tajne lekcje w programie nauczania szkolnego zainicjowała, w 1944 r., w KL Stutthof H. Strzelecka. Sama wybrała nauczycielki-więźniarki, przydzielając każdej po kilka uczennic. Uczestniczyły one m.in. w lekcjach języka polskiego, angielskiego, historii, matematyki i geologii ${ }^{67}$. Realizowano dwa programy nauczania. Dla starszych dziewcząt materiał szkoły średniej, a dla młodszych szkoły podstawowej. Zajęcia odbywały się wieczorami w sztubach lub podczas spacerów na ulicy obozowej. Ponadto, jak wspomina H. Jarocka, więźniarki-nauczycielki przy każdej nadążającej się okazji starały się uczyć młodsze dziewczęta poprawnej wymowy języka ojczystego ${ }^{68}$. Uczęszczająca na tajne lekcje M. Liberacka

${ }^{63} \mathrm{~W}$ zbiorach AMS zachowało się wiele tego rodzaju dokumentów. Należy do nich m.in. twórczość obozowych poetek - W. Felchnerowska, H. Banasiak czy Stefanii Łozińskiej. Część z nich opublikowano w książce pt. Stutthof w kobiecych narracjach. W 2012 r. w całości wydano bajki napisane w KL Stutthof przez H. Banasiak. Zob. H. Banasiak, Bajki, Sztutowo 2012, ss. 40. Poezja obozowa zebrana przez H. Jarocką znajduje się także w zbiorze AMS, Relacje $i$ wspomnienia, t. X, s. 167-180. W archiwum rodzinnym L. Zięby jest także bajka napisana przez H. Jarocką w 1944 r. w KL Stutthof pt. Serduszko królewny (kopia w zbiorach autorki). Poezja napisana w KL Stutthof przez H. Banasiak znajduje się w zbiorach Fundacji Generał Elżbiety Zawackiej, Dział: Archiwum Pomorskie (dalej cyt.: FGEZ, AP), K:164/164.

${ }^{64}$ AMS, H. Jarocka, Relacje i wspomnienia, t. XVIII, s. 79.

${ }^{65}$ Ibid.

${ }^{66}$ Ibid., s. 90.

${ }^{67} \mathrm{~W}$ zbiorach Muzeum Stutthof zachowały się notatki do nauczania niektórych przedmiotów: http://stutthof.org/node/487 [dostęp 28 XI 2018].

${ }^{68}$ AMS, H. Jarocka, Relacje i wspomnienia, t. XVIII, s. 88-89. 
wspominała, że dzięki konspiracyjnemu nauczaniu, zorganizowanemu w KL Stutthof, po wojnie bez problemu mogła kontynuować edukację w szkole ${ }^{69}$.

Istotnym elementem tworzenia kobiecej wspólnoty była również podziemna działalność harcerska ${ }^{70}$. Potajemne zbiórki odbywały się w warsztacie wyrobów ze słomy i celofanu, do którego posiadano klucz. Przy sprzyjających okolicznościach wykorzystywano go także jako „harcówkę". Według wspomnień H. Jarockiej był on wówczas specjalnie ozdabiany: „Na przedniej ścianie wisiała duża, artystycznie wykonana lilijka i hasło »Czuwaj«. Na stole leżała serweta i wycinanka z papieru. Dekoracje wykonała Janka Paradowska. Przy piecu znajdował się też sążek drewek"71. Dla podniesienia rangi owych zbiórek młodsze więźniarki jesienią 1944 r. złożyły harcerskie przyrzeczenie ${ }^{72}$. Trudno jednak określić, ile dziewcząt uczestniczyło w tego rodzaju spotkaniach. Biorąc pod uwagę okoliczności, ich konspiracyjny charakter, było to najprawdopodobniej zaledwie kilka więźniarek.

Rozmaite formy tajnego nauczania - od wieczornych dyskusji na obozowych pryczach, improwizowanych szkoleń i kursów, po zbiórki harcerskie - przynosiły wymierne korzyści uczennicom, chronionym $\mathrm{w}$ ten sposób przed demoralizującym wpływem obozowego środowiska. Dobrze oddają to fragmenty relacji K. Bartel, która w następujących słowach scharakteryzowała działalność edukacyjną W. Felchnerowskiej: „starała się zainteresować je nauką, żeby oddalić zło [...] Wala Felchnerowska fizycznie słaba, była bardzo ofiarna. Gdy zauważyła, że młodsze koleżanki mają zaburzenia nerwowe, zabawiała je dowcipami, wierszykami i piosenkami. Podziwiałam ją mówiąc: skąd u ciebie tyle humoru? Powiedziała: to nie jest szczere, ale trzeba ratować młodzież"73.

Ważnym elementem podejmowanych przez więźniarki prób zachowania godności ludzkiej było szeroko rozumiane pamiętnikarstwo. Próbowały one sporządzać notatki, dokumentując w ten sposób osobiste przeżycia, a także ważne wydarzenia z życia obozowego. Wiele z nich prowadziło pamiętniki, których oryginały niekiedy do dziś są $\mathrm{w}$ posiadaniu rodzin. Część tych niezwykle osobistych świadectw znajduje się

${ }^{69}$ AMS, M. Liberacka, Relacje i wspomnienia, t. IX, s. 78.

${ }^{70}$ Konspiracyjna działalność harcerska nie była charakterystyczna wyłącznie dla więźniarek KL Stutthof. Funkcjonowała ona m.in. w KL Ravensbrück. Zobacz o tym szerzej: D. Brzosko-Mędryk, Mury w Ravensbrück, Warszawa 1979, ss. 227; „Mury” harcerska konspiracyjna drużyna w Ravensbrück. Wspomnienia, oprac. Andrzej Szefer, Katowice 1986, ss. 260.

${ }^{71}$ AMS, H. Jarocka, Relacje i wspomnienia, t. XVIII, s. 90-91.

${ }^{72}$ Ibid.

${ }^{73}$ FGEZ, AP, K:78/78, wspomnienie K. Bartel o W. Felchnerowskiej, s. 8; FEGZ, AP, K:127/127, relacja K. Bartel-Rogozińskiej, s. 15. 
także w Archiwum Muzeum Stutthof ${ }^{74}$. Jednym z bardzo ciekawych artefaktów, potwierdzających kronikarską działalność więźniarek, jest pudełko na przybory do szycia należące do H. Chrzanowskiej ${ }^{75}$. Znajdują się na nim wiadomości zaszyfrowane w następujący sposób:

Niewol.18/8-21/8 +++ - oznacza on przywiezienie grupy jeńców sowieckich w dniu 18 VIII 1944 r. i zamordowanie ich w komorze gazowej 21 sierpnia.

Znicz 19/8 - nawiązuje do wysokiej śmiertelności w KL Stutthof. Więźniarki w dniu 19 VIII 1944 r. zaobserwowały bardzo wysoki płomień wychodzący z komina krematorium.

26/9 transport powst. warsz. - H. Chrzanowska oznaczyła w ten sposób transport powstańców warszawskich i ludności cywilnej do obozu. $\mathrm{W}$ dacie jest jednak błąd, ponieważ miał on miejsce 29 , a nie jak zaznacza autorka - 26 IX 1944 r.

Wieczorek Br. 45155 - zapis dotyczy więźniarki Bronisławy Wieczorek, nr obozowy 45 155, którą powieszono w Stutthofie we wrześniu $1944 \mathrm{r}$.

Stos 10/1.45 - adnotacja informująca o zorganizowaniu w styczniu 1945 r. stosów całopalnych.

Genia 10.07.1944 - informacja o zamordowaniu Genowefy Młynarz (siostry H. Chrzanowskiej) w dniu 10 VII 1944 r. w Berlinie $^{76}$.

Próby ratowania psychiki więźniarek mogły osiągnąć swój cel tylko wtedy, gdy równolegle towarzyszyły im akcje dożywiania, zapewnienie opieki w przypadku choroby, organizacja odzieży, a także umieszczenie $\mathrm{w}$ dobrym komandzie pracy. Tego rodzaju pomoc była niezwykle potrzebna i dająca wymierne efekty, jednakże jej realizacja nastręczała kobietom największych trudności. Wykrycie kradzieży obozowego mienia, nazywanej przez więźniów „organizowaniem”, mogło zakończyć się ciężkimi represjami - karą bunkra, chłostą czy skierowaniem do karnej kompanii ${ }^{77}$. „Organizowanie” praktykowano przede wszystkim w warsztatach rzemieślniczych, magazynach odzieżowych, kuchni czy

${ }^{74}$ W 2017 r. do Muzeum Stutthof w Sztutowie przekazano notatnik Zofii Odechowskiej ps. Lenka, w którym znajduje się opis doświadczeń kobiet jeńców wojennych przywiezionych do KL Stutthof 29 IX 1944 r. http://stutthof.org/node/960 [dostęp 22 XI 2018].

${ }^{75}$ Obecnie pudełko przechowywane jest w Zbiorach Muzeum Ziemi Chełmińskiej. Fotografie artefaktu znajdują się w zbiorach autorki.

${ }^{76} \mathrm{H}$. Chrzanowska sporządziła także instrukcję do rozszyfrowania zapisków z pudełka. Jej kopia znajduje się w zbiorach Fundacji Generał Elżbiety Zawackiej: FGEZ, AP, K:58/58, s. 13-14.

${ }^{77}$ Szerzej o tzw. organizowaniu zob. Auschwitz od A do Z..., s. 124. 
podczas prac $w$ komandach zewnętrznych. Zdobyte towary wymieniano na tzw. czarnym rynku, nazywanym od 1944 r. na wzór warszawskiego targowiska kercelakiem ${ }^{78}$.

Najwyższą walutę w obozowym systemie wymiany stanowiła żywność. Jej dodatkowe porcje można było pozyskać na kilka sposobów - poprzez kradzież z miejsca pracy, wymianę z innymi więźniami lub robotnikami cywilnymi, tzw. zulagi (dodatkowe przydziały chleba lub zupy wydawane niektórym więźniom), a także paczki przesyłane przez rodziny i znajomych. Więźniarki starały się solidarnie dzielić gromadzonymi zapasami żywności, wspierając te, które nie miały możliwości otrzymania dodatkowych racji. Niejednokrotnie zdarzało się, że zawartość paczki nadesłanej do Stutthofu nie nadawała się do spożycia. Przesyłki docierały do obozu po długim czasie od nadania, co często skutkowało zepsuciem ich zawartości ${ }^{79}$. Tego rodzaju sytuacje doprowadzały więźniarki do załamania, z którego ratowały je wsparcie i solidarność koleżanek. Jak wspomniała H. Jarocka, szczodrością w dzieleniu się zawartością otrzymanych paczek szczególnie odznaczała się m.in. K. Bartel, która: „zawsze potrafiła wytropić najgłodniejszą z nas i podzielić się z nią tym, co miała najlepszego. Jak najdelikatniej, bez zwracania uwagi to czyniła"80. Inna więźniarka, Zofia Kopeć, podkreślała, że niezwykłe wsparcie otrzymywała ze strony duńskich komunistek, które przysyłały wysokokaloryczne paczki za pośrednictwem Czerwonego Krzyża ${ }^{81}$. Kobiety znajdowały rozmaite drogi w pozyskiwaniu dodatkowego jedzenia. Te, które zatrudniono przy sprzątaniu komendantury, narażały się, wykradając jedzenie należące do SS. Maria Pitera-Zalewska wspomniała, że przy sprzyjających okolicznościach udało jej się nawet „zorganizować" alkohol ${ }^{82}$.

Niestety, spontaniczne, nieprzemyślane akcje pomocowe mogły zakończyć się tragicznie. Obrazuje to relacja H. Jarockiej, która opowiada o próbie dostarczenia żywności rosyjskim więźniom. Kobiety pracując poza obozem, przy kopcach z marchwią, postanowiły rzucić zbierane warzywa znajdującym się w pobliżu mężczyznom. Jeden $\mathrm{z}$ nich, zaślepiony głodem, nie zwrócił uwagi na obserwującego go nadzorcę. Według niej: „Więzień nie słyszał naszych ostrzeżeń. Kapo (Niemiec z zielonym winklem) rzucił się z łopatą na więźnia. Uderzył go kilka razy, wrzeszcząc, żeby oddał marchew. Głód jednak był silniejszy od strachu i więzień nie pozwolił sobie odebrać zdobyczy. Kapo rozwścieczony oporem

\footnotetext{
${ }^{78}$ W. Ostrowski, Warszawiacy w Stutthofie, wyd. II uzup., Warszawa 2014, s. 85.

${ }^{79}$ FGEZ, AP, relacja Apolonii Deyk, K:409/409, s. 5.

${ }^{80}$ AMS, H. Jarocka, Relacje i wspomnienia, t. XVIII, s. 102.

${ }^{81}$ FGEZ, AP, K:101/101, relacja Zofii Kope, s. 16.

${ }^{82}$ AMS, M. Pitera, Relacje i wspomnienia, t. XV s. 273.
} 
bił go tak długo, aż zabił. Biedny, głodny więzień upadł martwy na plecy $\mathrm{z}$ marchwią sterczącą $\mathrm{w}$ ustach. Było to dla nas straszne przeżycie" ${ }^{83}$.

Poza organizacją żywności niezwykle istotne było zaopatrzenie się w dodatkową odzież i obuwie, a także możliwość utrzymywania jej w czystości. Więźniarki miały dość duże pole do działania w tej materii, ponieważ wiele $z$ nich pracowało $w$ obozowych szwalniach, warsztatach futrzarskich, szewsko-rymarskich czy pralni ${ }^{84}$. Kobiety przemycały z nich materiał do reparacji starych ubrań, czystą bieliznę, a nawet dodatkową odzież, zaopatrując w nie najbardziej potrzebujące. C. Ciesielska wspominała, że pracując $w$ warsztacie wyrobów ze słomy, za pośrednictwem Mieczysława Goncarzewicza nawiązała kontakt z więźniami należącymi do ruchu oporu, którzy poprosili o wsparcie przy dostarczaniu czystej bielizny ${ }^{85}$.

Szeroko rozumiana samopomoc wiązała się z wykształceniem wśród społeczności więźniarskiej całego systemu powiązań i zależności. Za każdą przysługę należało się zrewanżować ${ }^{86}$. W relacjach kobiet znajduje się wiele wzmianek o swego rodzaju wymianie barterowej pomiędzy więźniami. H. Jarocka zaopatrywanie więźniów w „zorganizowaną" odzież określała także mianem „dostarczania jej do klienteli”. Wspomina również, że dzięki współpracy z mężczyznami udawało im się m.in. otrzymać tytoń (którego kobiety nie mogły kupować w obozowej kantynie), przesyłać wewnątrz obozu nielegalną korespondencję, a także pomagać najbliższym uzyskać zatrudnienie $\mathrm{w}$ dobrym komandzie pracy. W relacji tej czytamy m.in.: „Było bowiem sporo kobiet, których mężowie, ojcowie, bracia czy sympatie przebywali w męskim obozie, dokąd kobiety nie miały wstępu. Dlatego też różnymi drogami kombinowano przesyłki bielizny, swetrów, żywności i listów. Od nowego roku 1944 poczta funkcjonowała poprzez Schusterei [zakład szewskiego - W.W.]. Inicjatorem jej był Mietek Goncarzewicz. Z rana po wejściu do warsztatu ja jako Schreiber, miałam obowiązek wręczyć Czechowi listy, które pozbierałam od kobiet, a on z kolei wydawał listy, jakie przyszły do nas od mężczyzn. Pocztę tę szybko rozdzielałam adresatkom. Pocztę przeznaczoną na lagier męski Czech przykrywał wzorcami prac i później odnosił je adresatom" 87 .

Niezwykle ważną działalnością w strukturze samopomocy była opieka nad najsłabszymi, najbardziej bezbronnymi więźniami - dziećmi i osobami starszymi. W 1944 r., w transportach z Mińska, Rygi i Białe-

\footnotetext{
${ }^{83}$ AMS, H. Jarocka, Relacje i wspomnienia, t. XVIII, s. 79.

${ }^{84}$ Szerzej o pracy kobiet w KL Stutthof zob. M. Orski, op. cit., s. 141-194.

${ }^{85}$ FGEZ, AP, K:20/20, relacja C. Ciesielskiej, s. 13.

${ }^{86}$ W. Ostrowski, op. cit., s. 89.

${ }^{87}$ AMS, H. Jarocka, Relacje i wspomnienia, t. XVIII, s. 94-95.
} 
gostoku, do KL Stutthof trafiła duża liczba małoletnich i dzieci ${ }^{88}$. Szczególne zainteresowanie więźniarek wzbudziły transporty, z 15 I i 10 II tego roku, w których znalazło się 29 dzieci w wieku 4-16 lat. Starszych chłopców umieszczono w barakach męskich w nowym obozie, a młodsze dzieci, oddzielone od matek, znalazły się w bloku nr 5 w starej części Stutthofu, gdzie przeniesiono także kobiety ciężarne i matki z nowo narodzonymi niemowlętami ${ }^{89}$. Mimo iż wstęp do tzw. bloku dziecięcego był zabroniony, konspiratorki-więźniarki, głównie J. Rotecka i H. Chrzanowska, postanowiły zorganizować pomoc. Żywność dostarczano dzięki współpracy z pracownikiem kuchni, więźniem Janem Kroplewskim, a także ofiarności osób, które oddawały część swoich przydziałów ${ }^{90}$. Ubranka dla dzieci i odzież dla matek wykradano z obozowej pralni. Ponadto więźniarki pracujące $\mathrm{w}$ zakładach krawieckich dostarczały nielegalnie sporządzone piłki, misie i lalki. Natomiast drewniane zabawki wykonywali więźniowie pracujący w stolarni ${ }^{91} .28$ III $1944 \mathrm{r}$. dzieci te, wraz z matką jednego z nich, odesłano do obozu w Konstantynowie Łódzkim, utworzonego dla dzieci białoruskich, ukraińskich i rosyjskich, które uznano za nadające się do germanizacji ${ }^{92}$.

Innym, niezwykle istotnym miejscem w strukturze kobiecej samopomocy był szpital. Początkowo (w latach 1940-1942) chore więźniarki umieszczano $\mathrm{w}$ oddzielnej sali przeznaczonej dla mężczyzn (tzw. Krankenbaum), znajdującej się w bloku nr IV na terenie starego obozu. W 1942 r., w związku ze zwiększeniem liczby więźniarek (do około 100) władze obozowe utworzyły tzw. Krankenstubę w bloku nr I, czyli niewielką kobiecą filię głównego szpitala ${ }^{93}$. Najcięższe warunki pracy w nim

${ }^{88}$ Zob. szerzej A. Kłys, Nieletni więźniowie w KL Stutthof. Próba statystyki, [w:] Dzieci wojny, pod red. A. Bartuś, Oświęcim 2016, s. 121.

${ }^{89}$ J. Grabowska, Martyrologia dzieci i młodzieży w obozie koncentracyjnym Stutthof, [w:] Dzieci i młodzież w latach drugiej wojny światowej, pod red. C. Pilichowskiego, Warszawa 1982, s. 172.

${ }^{90}$ FGEZ, AP, K:58/58, relacja H. Chrzanowskiej, s. 5-6.

${ }^{91}$ J. Grabowska, Martyrologia dzieci i mtodzieży..., s. 173.

${ }^{92}$ Ibid.

${ }^{93}$ Łącznie składała się ona z czterech pomieszczeń (w 1944 r. doszło jeszcze piąte). Dwie większe sale przeznaczono dla zakaźnie chorych (biegunka, tyfus), w pozostałych pomieszczeniach mieściły się gabinet lekarski i zabiegowy. Bezpośrednią kontrolę nad tzw. Krankenstubą miał szef administracyjny całego szpitala Otton Haupt. Szpital kobiecy nie miał swoich lekarzy. Pracowali tam lekarze więźniowie z części męskiej, przeważnie ginekolodzy. W 1942 r. opiekę nad chorymi sprawował przede wszystkim dr Bogdan Jasiński, a po jego zwolnieniu, tj. od 1943 r., dr Józef Roszkowski i Anna Paszkowska. Funkcję salowych i pielęgniarek pełniły więźniarki, m.in. Zofia Piasecka, D. Szklarska i Felicja Sławińska. Więcej na temat obozowego szpitala zob. M. Gliński, Organizacja i obsada personalna szpitala w obozie koncentracyjnym Stutthof, Zeszyty Muzeum Stutthof 1976, nr 1. 
przypadały na lata 1941-1943. Ich powodem były nie tylko brak odpowiedniego wyposażenia, pusta lub słabo zaopatrzona apteczka, ale przede wszystkim permanentna zależność od lekarzy, sanitariuszy SS oraz różnego rodzaju więźniów funkcyjnych. Mimo trudnej sytuacji więźniarski personel starał się za wszelką cenę wypełniać swoje obowiązki i udzielać chorym maksimum opieki. Także $\mathrm{w}$ tym wypadku dużą rolę odgrywała pomoc psychologiczna, przeświadczenie o opiece i wsparciu ze strony drugiego człowieka. Jak pisał psychiatra Antoni Kępiński: ,jeżeli w szpitalu obozowym ludzie z ciężkich chorób somatycznych wracali do zdrowia, to nie dzięki lekom, których prawie nie było, ale dzięki postawie kolegów więźniów, lekarzy, pielęgniarzy i rekonwalescentów. Był to chyba najpiękniejszy rozdział w psychoterapii" ${ }^{94}$. Podobną opinię wyraziła lekarka Anna Paszkowska - która w KL Stutthof opiekowała się chorymi kobietami - „Środki były niesłychanie proste, prymitywne. Miałyśmy strzykawki, miałyśmy dość dużo glukozy, która nie jest lekiem na tyfus, ale jest już czymś choćby na podtrzymanie serca. Poza tym chore miały świadomość, że coś im się daje" ${ }^{\prime 95}$.

Kobiety wspominają, że w szpitalu stykały się ogromną ofiarnością i wsparciem ze strony personelu. Więźniarka Irena Chojnacka podkreślała, że mimo beznadziejnego stanu zdrowia dr Bogdan Jasiński i pielęgniarki uratowali ją dzięki zorganizowanym potajemnie wzmacniającym zastrzykom i dodatkowej żywności ${ }^{96}$. Wykradaniem lekarstw zajmowało się komando sprzątające budynki w części esesmańskiej. Jego członkinie posiadały specjalne przepustki, które gwarantowały im wstęp do biur, pokojów, a także na teren szpitala SS. Więźniarka Maria Pitera-Zalewska wspomina, że dzięki licznym kontaktom wynosiła z gabinetów lekarskich glukozę, kamforę i inne lekarstwa ${ }^{97}$. Część z tych leków przemycano także na rewir męski ${ }^{98}$. $Z$ relacji kobiet wynika także, że $w$ wielu wypadkach lekarze-więźniowie starali się jak najdłużej zatrzymywać chore w szpitalu. Była to jedyna szansa, aby mogły odpocząć od ciężkiej pracy.

Trzeba zaznaczyć, że udzielanie pomocy chorym $\mathrm{w}$ tak skrajnych warunkach wiązało się nie tylko $\mathrm{z}$ narażeniem na rozmaite konsekwencje ze strony władz obozowych, ale przede wszystkim z wieloma problemami etycznymi i moralnymi. Liczba miejsc w szpitalu była niewielka,

${ }^{94}$ Cyt. za: A. Kępiński, Rytm życia, Kraków 1978, s. 99.

${ }^{95}$ AMS, A. Paszkowska, Relacje i wspomnienia, t. XV, s. 137-138. Warto zauważyć, że Anna Paszkowska kontynuowała opiekę lekarską także po ewakuacji Stutthofu. W zbiorach FGEZ zachowały się prowadzone przez nią karty chorych: FGEZ, AP, K:166/166, k. 7 (s. 1-14).

${ }^{96}$ AMS, I. Chojnacka, Relacje i wspomnienia, Archiwum Muzeum Stutthof, t. XV, s. 9.

${ }^{97}$ AMS, M. Pitera-Zalewska, Relacje i wspomnienia, t. XV, s. 262-263.

${ }^{98}$ AMS, A. Paszkowska, Relacje i wspomnienia, t. XV, s. 135. 
a przyjmowanie zbyt wielu pacjentów tylko pogarszało warunki sanitarne. Medykamentów nie wystarczało dla wszystkich, lekarze musieli więc decydować, komu przyniosą one największą pomoc. $Z$ takimi dylematami zmagała się m.in. Z. Piasecka ${ }^{99}$. Przez wiele więźniarek charakteryzowana była jako osoba surowa, pozbawiona empatii i skoncentrowana na własnych interesach. „Piasecka była bardzo sucha, była starym numerem, a oni nigdy nie zrobili więcej niż było wolno" - wspomina E. Marcinkowska-Szuca ${ }^{100}$. Według relacji Marii Pitery-Zalewskiej postawa Piaseckiej nie była podyktowana złą wolą, a ciężką sytuacją panującą w szpitalu ${ }^{101}$.

Jesienią 1944 r. w związku ze wzrostem liczby więźniarek utworzono izbę dla chorych kobiet w bloku $\mathrm{nr} 26$ na terenie nowego obozu. Składała się z dwóch sztub, w których izolowano cierpiące na dur plamisty i gruźlicę. Nadzór nad nimi objęła dr A. Paszkowska. Z dostępnych relacji wynika, że prowadzono tam największe akcje samopomocy więźniarskiej. A. Paszkowska wspominała, że „w tym czasie inspekcje esesmanów i nadzorczyń były stosunkowo rzadkie. Personel szpitala w bloku 26, tworzył zgrany zespół łączniczek i sanitariuszek przywiezionych do Stutthofu po Powstaniu Warszawskim. Podobnie jak w przypadku Krankenbau w Starym Obozie, zaopatrzenie w lekarstwa, środki opatrunkowe, czystą bieliznę i żywność było niewystarczające. Personel szpitala przy ogromnym wsparciu kilku grup więźniów »organizował« je na własną rękę. Szczególnie korzystna była w tym przypadku bliskość kuchni więźniarskiej. Wykradano z niej różne produkty żywnościowe, starano się także o większe przydziały zupy dla chorych"102.

Ogromne wsparcie dla szpitala stanowili pracownicy Effektenkammer, czyli magazynów rzeczy odbieranych więźniom. Jeden z nich, Mieczysław Brzozowski, dostarczał czystą bieliznę i koce. Jak wspominał dr Julian Węgrzynowicz, szpital męski od 1943 r. był (jak na warunki obozowe) w miarę dobrze zaopatrzony ${ }^{103}$. Łącznikiem pomiędzy Krankenbau a blokiem 26 był wówczas więzień Stanisław Knopkiewicz. Pełnił on funkcję pisarza odpowiedzialnego za dokumentację szpitala i stan osobowy więźniów. Knopkiewicz posiadał przepustkę, dzięki której swobodnie poruszał się pomiędzy poszczególnymi częściami obozu. Za jego pośrednictwem przemycano zarówno lekarstwa, witaminy, jak i nielegalną korespondencję ${ }^{104}$. Jak wspomina A. Paszkowska, akcja sa-

\footnotetext{
${ }^{99}$ AMS, M. Pitera-Zalewska, Relacje i wspomnienia, t. XV, s. 263.

${ }^{100}$ AMS, E. Marcinkowska-Szuca, Relacje i wspomnienia, t. VI, s. 66.

${ }^{101}$ AMS, M. Pitera-Zalewska, Relacje i wspomnienia, t. XV, s. 263.

102 AMS, A. Paszkowska, Relacje i wspomnienia, t. VI, s. 31; t. XV, s. 138-137.

${ }^{103}$ AMS, J. Węgrzynowicz, Relacje i wspomnienia, t. VI, s. 249.

${ }^{104}$ AMS, Maria Klosek-Reiter, Relacje i wspomnienia, t. VI, s. 31.
} 
mopomocy prowadzonej w szpitalu zakończyła się wraz z ewakuacją Stutthofu. W 1945 r. zlikwidowano szpital w bloku 26, a wszystkich chorych przeniesiono do sztub na terenie starego obozu ${ }^{105}$.

Wymieniając poszczególne formy działalności konspiracyjnej kobiet w KL Stutthof, nie możemy zapomnieć o jednym - chyba najbardziej kojarzącym się z klasyczną definicją ruchu oporu - a mianowicie o sabotażu pracy. Więźniarki zatrudnione $\mathrm{w}$ rozmaitych warsztatach starały się w miarę możliwości opóźniać realizację przydzielanych im norm, a także wpływać na jakość produkowanych przez nie rzeczy. W relacjach kobiet pracujących w szwalni (Schneiderei), których zadaniem była reparacja mundurów, pojawiają się informacje o celowym szyciu słabymi ściegami i długimi nićmi, tak aby ich naprawa nie była efektywna ${ }^{106}$. Więźniarki zatrudnione $\mathrm{w}$ komandzie kuśnierskim (Pelzkammer) miały natomiast niszczyć najlepsze kawałki futra, z których szyto m.in. futrzane kamizelki czy spodnie ze skórek króliczych. Jak wspomina jedna z nich: "sporządzałyśmy kożuchy dla wojsk walczących na froncie wschodnim. Naszym majstrem był jakiś inwalida wojenny, cywilny fachowiec. Przycinałam skórę przy jednym stole z Helą Chrzanowską. Drobne odpadki pozwalał nam palić w stojącym w pobliżu żelaznym piecyku. Helusia Chrzanowska, wykorzystując okazję, zaproponowała, abyśmy cięły w kawałki najlepsze futra i paliły. Gdy tylko więc Aufseherka gdzieś odeszła, a majster patrzył w inną stronę, cięłyśmy te futra na kawałki zadowolone, że chociaż $\mathrm{w}$ ten sposób możemy posabotować" ${ }^{107}$. Trudno określić, czy wymieniane działania miały rzeczywisty wpływ na pogorszenie planów produkcyjnych obozu, niewątpliwie jednak dawały one więźniarkom poczucie spełnionego obowiązku.

Viktor Frankl zaznaczał, że „dla każdego człowieka nadchodzi w końcu dzień, gdy spogląda wstecz na swoje obozowe przeżycia i nie pojmuje, jakim cudem udało mu się przetrwać" ${ }^{\prime 108}$. Nie jesteśmy w stanie stwierdzić, ile osób, parafrazując przytaczane słowa, mogło stwierdzić, że przetrwało dzięki pomocy kobiet zaangażowanych w pracę konspiracyjną na terenie obozu koncentracyjnego Stutthof. Musimy pamiętać, że ta była poważnie ograniczona, $\mathrm{z}$ jednej strony przez charakter miejsca, $z$ drugiej ze względu na specyfikę funkcjonowania w nim kobiet. Możliwości ich działania były, tak jak w przypadku mężczyzn, najczęściej uza-

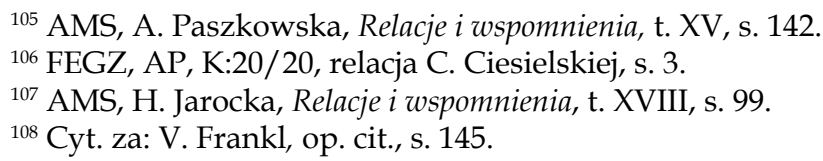


leżnione od komanda pracy, jednakże ze względu na płeć, zakres miejsc, w których mogły być zatrudnione, był poważnie ograniczony. Nie mogły one na przykład pracować $\mathrm{w}$ rusznikarni i zdobywać uzbrojenia, nie zatrudniano ich na ogół w biurach SS, co też poważnie ograniczało możliwości prowadzenia działalności konspiracyjnej. W odróżnieniu od mężczyzn tworzących w KL Stutthof wojskowy ruchu oporu nie posiadały one doświadczenia $w$ prowadzeniu bezpośredniej walki zbrojnej. Jednak podejmowana przez nie działalność znacznie wykraczała poza ramy funkcjonującej definicji obozowej samopomocy. Pomimo ograniczonych możliwości poprzez opiekę realizowaną $\mathrm{w}$ ramach szpitala, stymulowanie życia kulturalnego i religijnego, wkład na rzecz edukacji docierały ze wsparciem do szerokiego grona więźniarek. Ich działalność nadawała ponownie znaczenie niszczonym przez obozowy terror wartościom, takim jak współczucie i poszanowanie życia ludzkiego.

Samo uczestnictwo w konspiracji było również swojego rodzaju ratunkiem. Jak podkreślała A. Pawełczyńska: „Przynależność do obozowego ruchu oporu stanowiła największy przywilej. Wyższemu miejscu w hierarchii obozu, dzięki któremu zwiększały się szanse przetrwania, towarzyszyła świadomość uczestnictwa w walce. Członek organizacji obozowej nie był już tylko ściganym zwierzęciem, lecz stawał się we własnej świadomości pełnowartościowym człowiekiem, który walczy przeciw przestępcom" 109 .

Wielokrotnie przywoływane relacje, choć niezwykle ważne, ukazują tylko fragment historii kobiecej konspiracji w KL Stutthof. Do opowiedzenia jej w całości niezbędne są prowadzone na szeroką skalę badania empiryczne i komparatystyczne, obejmujące również relacje więźniarek innych narodowości. Bez ukazania losów kobiet-konspiratorek w szerszym kontekście historia obozu koncentracyjnego Stutthof pozostanie niepełna.

${ }^{109}$ Cyt. za: A. Pawełczyńska, op. cit., s. 145-146. 